\title{
Work Environment and Work Stress Affecting Nurse Performance (Study Hospitals in Indonesia)
}

\author{
Dwi Nugraheni Sakti Prabawanti ${ }^{1}$, Ratna Indrawati $\mathbf{L}^{2}$ \\ University of Esa Unggul ${ }^{1,2}$
}

\begin{abstract}
In each field of work, the performance became the final value which became a measure of one's success in carrying out their work without exception the nurse profession. For that matter, this study aims to know the factors that influence nurse performance. The work environment is the atmosphere of the location when a job is done either in a permanent or non-permanent place then physically and non-physically, the work environment is one of the factors that can improve performance and a good and pleasant work environment can do every job well. Then work stress is also a factor that can affect a person's performance, someone with a high level of work stress will find it difficult to achieve good performance and vice versa. This study examined respondents in one hospital in Indonesia and involved 160 respondents using Structural Equation Modeling (SEM) method. This study examined three hypotheses, namely the influence of the work environment on nurse performance and work stress and the effect of work stress on performance with work stress was also an intervening variable between the relationship between the work environment and nurse performance. The results of this study indicate that the work environment has an influence on work stress and work performance and stress has an influence on performance and in this study shows that work stress is also an intervening variable in the relationship of work environment with performance.
\end{abstract}

Keywords: Work Environment, Job Stress, Nurse Performance, Intervening Variable

\section{INTRODUCTION}

Facing the era of globalization, health services want to improve the quality of services offered to the public. Service quality can be used as a tool to achieve competitive advantage. One of the health service facility services is a development center that has the aim of fostering community participation, providing comprehensive and integrated services. As people care more about their health, the higher the demands of the community for the quality of health services provided by the Hospital, especially in terms of nursing care.

Nurses are one component which have an important role in providing health services in hospitals. Naharudin \& Sadegi (2013) suggested that the work environment is one of the factors that most influence performance and determine the level of work stress. Khuong \& Yen (2016) suggested that work stress is an intervening variable in the relationship of work environment and employee performance. Jehangir, et al (2011) in their research in one of the Pakistan Hospitals stated that work stress is one of the factors that influence the level of performance of female nurses. The research of Ahmed \& Raman (2013) also stated that any increase in stress levels will reduce the level of performance. Various situations and demands for work experienced can be a potential source of stress.

The results of Jayaweera's research (2014) stated that companies must consider improving their work environment so that they can improve the performance produced. The most potential thing that can cause stress is when the workload is not balanced and can interfere the work. If the task load cannot be anticipated properly it will result in the inability of a person to interact positively with his environment, both in the work environment and the environment outside of his work. The results of Omari \& Okasheh's research (2017) stated that dissatisfaction with the work environment make a decrease in performance achievements.

Based on the Decree of the Minister of Health of the Republic of Indonesia No. 340 / MENKES / PER / III / 2010 hospital is a health service institution that organizes plenary individual health services, namely: inpatient care, outpatient and emergency care. Regulation of the Minister of Health of the Republic of Indonesia No. 1204 / Menkes / SK / X / 2004 concerning the Environmental Health Requirements of Hospitals, stating that hospitals are health service facilities, a gathering place for sick and healthy people, or can be a place for transmitting diseases and enabling environmental pollution and health problems. From the above understanding, the hospital carries out several types of services including support, care, rehabilitation, prevention and improvement of health, as a place of medical education and medical care, as a place for developing science and technology, and to avoid the risks and health problems as intended, so that organizing the health of the hospital environment in accordance with health requirements. 


\section{International Advanced Research Journal in Science, Engineering and Technology}

Vol. 6, Issue 1, January 2019

Atma Jaya Hospital as one of the health care providers is required to always improve service quality through the performance of nurses in carrying out nursing care to patients. Various complaints of fatigue experienced by nurses in carrying out work and some complaints about the work environment both physically and non-physically affect emotions, thoughts, and physical conditions that have an impact on the emergence of symptoms of work stress. In this study we examined the influence of the working environment on the performance of nurses with job stress as an intervening variable. The working environment in terms of physical (temperature, air circulation, the size of the workspace, noise, lighting, room layout, and work equipment) and non-physical (relationships among colleagues, relations with superiors and subordinates, and job security) Performance in terms of quality of work, creativity, work, job knowledge. Work stress in terms of intimidation and pressure, incompatibility with work, dangerous work, workload, targets and unrealistic expectations.

At present, Atma Jaya Hospital has carried out various strategies in improving nurse performance through work direction but still found problems, namely nurses experiencing work fatigue, burnout, and stress that have an impact on decreasing nurses' performance in implementing nursing care. From the description of the background above, the purpose of the research to be achieved: to know the influence of the work environment on nurse performance; to know the influence of the work environment on the stress of nurse work; to know the influence of work stress on nurse performance.

\section{LITERATURE REVIEW}

\section{Work Environment}

Work environment according to Render \& Heizer (2001) namely the physical environment where employees work which affects performance, safety and quality of work life. A conducive work environment provides a sense of security and allows for optimal work. According to Noah \& Steve (2012) the work environment is the overall relationship that occurs with employees in the workplace. The work environment includes working relationships formed between fellow employees and work relationships between subordinates and superiors and the physical environment of the workplace. The work environment is a collection of factors that are both physical and non-physical, where both affect the way they work. Functional comfort can be defined as the rate at which employees can carry out their duties in their current workplace environment (Visher, 2008).

The physical work environment is the center of work, chairs, tables, temperature, humidity, air circulation, lighting, noise, mechanical vibration, odor, and color. Non-physical work environment that is all the conditions that occur that are related to work relationships, both relationships with superiors and relations with fellow colleagues or relationships with subordinates. Sedarmayanti (2013) suggested that the measurement of work environment includes lighting, noise, air temperature, air circulation, workspace size, privacy of the workspace, room layout, work security, work equipment, relationships with colleagues, relationships with superiors and subordinates.

\section{Work Stress}

Anderson (2002), family conflict is also the root that creates employee stress. Job stress according to Schult \& Schult (2006) is a psychological symptom that is felt disturbing in the implementation of tasks thus it can threaten selfexistence and well-being. Stress is defined as a situation that requires more physical and mental energy than normal. A pressure that results when someone sees a situation that requires capability or resources beyond its capabilities. Stress is associated with limitations and requests. Job stress arises because of the demands of the environment, namely a condition of tension that affects emotions, the process of thinking and the condition of a person where he is forced to respond beyond his ability to adjust to an external (environmental) demand. Job stress that is too large can threaten a person's ability to deal with his environment.

Research conducted by Khuong \& Yen (2016) stated that work stress is an intervening variable in the relationship of work environment and employee performance. According to Igor (1997) work stress can be caused by: intimidation and pressure from co-workers, company leaders and clients, the difference between the demands and available resources to carry out tasks and obligations, incompatibility with work, work that are dangerous, frustrating, boring or repetitive, excessive load.

\section{Performance}

Viswesvaran and Ones (2000), Job performance is work behavior that is relevant to organizational goals, in individual control, and can be measured, observable, scorable, etc. In addition, the total output recognized by employees contributing to the organization is another definition of job performance. This is the number of opportunities, abilities, and motivation. Hunter (1984) said that organizations pay a lot of attention to job performance because of the importance of high productivity. Campbell (1990), job performance is something that is done individually, and has its own level of variable. Therefore, it can be separated from other terms such as national performance or organizational performance with higher level of variables. They mentioned work performance which included observable actions that 


\section{International Advanced Research Journal in Science, Engineering and Technology}

Vol. 6, Issue 1, January 2019

people made in their work related to company goals. Campbell, et al (1993) explained job performance is behavior itself is not a consequence of behavior. Like the same meaning, job performance includes behaviors that really involve employees and can be observed.

According to Motowidlo, et al (1993), work performance is behavior not outcome even though he emphasizes evaluative ideas in defining job performance. And behavior must be relevant to organizational goals is one of the further elements of job performance. Employee performance according to Robbins \& Judge (2012) is basically the ability of employees to deal with work and positive attitudes shown by employees in the workplace. The ability to complete the work means that the employee is able to finish the job well (in accordance with predetermined standards) and the employee behaves positively as indicated by his attitude to comply with company regulations, and others. The component of employee performance includes three components, namely: task performance, citizenship, and counterproductivity.

Performance in The Scribber Bantam English Dictionary is defined as: to do or carry out execute, to discharge of fulfil as a vow, to portray, as character in a play, to render by the voice or musical instrument, to execute or complete an undertaking, to act a part in a play, to perform music, to do what is expected of a person or machine" (Sedarmayanti, 2013). According to the research of Donnellu, Gibson, \& Ivancevich in Rivai (2008) individual performance can be improved if the match between work and ability goes well. Factors that influence performance achievement are abilities and motivation. The ability factor is that psychologically employees have potential abilities (IQ) and reality abilities. Motivational factors are formed from the attitude of an employee in the face of work situations.

\section{HYPOTHESIS DEVELOPMENT}

Render \& Heizer (2001) suggested that workplaces always demand that every employee work productively. A comfortable and conducive work environment cannot be separated from the factors of room coloring, office cleanliness, air transportation, lighting, security and noise in the work area so that it is worth noting, prepared and planned carefully because these things greatly affect the physical condition and psychology of employees as well as the relationship between employees is also worth noting. Noah \& Steve (2012) argued that the work environment is not only physical but also non physical which includes the atmosphere and relations between employees where in this case the hospital must be able to help establish good relations between employees both between superiors and subordinates and subordinates. This is in line with researchers Omari \& Okasheh (2017); Jayaweera (2014); Naharudin \& Sadegi (2013) who concluded that the better the work environment, the more positive the effect on performance. Based on the literature above the hypothesis that can be proposed:

$\mathrm{H}_{1}$ : Better environment can increase working performance.

Job stress is determined by the work environment of the Hospital. The lower the level of stress the nurse works, the better the work environment in the hospital and vice versa when the nurse has a high level of stress, the environment in the hospital is not good and has a negative influence on the level of stress in the work environment. This is in line with the research of Khuong \& Yen (2016) and Thayer, et al, (2010) which concluded that the work environment is one of the factors that determine the level of work stress because it is the main thing that is directly felt by employees and has a direct effect besides also found that work stress is an intervening variable in the relationship of work environment and employee performance. Based on the literature above the hypothesis that can be submitted:

$\mathrm{H}_{2}$ : Better environment can lower stress level.

Nurse performance is determined by the stress of work experienced. The lower the level of work stress, the higher the performance of nurses in the hospital and vice versa when nurses have high stress levels, the nurse's performance will decrease. This is in line with the research of Jehangir, et al (2011); Zafaar, et al (2015) and Ahmed \& Raman (2013) who concluded that work stress is one of the factors that influence the level of performance of female nurses in a hospital in Pakistan. The results of this study also further support that high levels of performance due to low stress levels in nurses, of course this is very appropriate that each nurse who does not experience stress in the work will produce a better level of performance because it will focus on the work provided and will provide the best service to patients. Based on the literature above the hypothesis that can be submitted:

$\mathrm{H}_{3}$ : Lower stress level can increase working performance.

\section{RESEARCH METHOD}

This research was conducted on nurses who served at Atma Jaya Hospital. The variables studied were work environment, work stress, and performance. The study was conducted in August 2018 with quantitative methods. This research is descriptive. Data collection was done by distributing questionnaires to all nurses, both outpatient and inpatient. The method of data analysis in this study used Structural Equation Modeling (SEM). Hair, et al (2013) must have at least 5 times the number of questionnaires so that in this study the number of operational questionnaires used 


\section{International Advanced Research Journal in Science, Engineering and Technology}

Vol. 6, Issue 1, January 2019

was 45 questions, so that 45 times the 5 indicator indicators whose results totaled 225 plus $10 \%$ for indications of dropout from the study so the overall total became 248 sample, but in this study experienced a shortage of samples because the number of nurses in Atma Jaya Hospital amounted to 165, so in this study it done using saturated samples that were all nurses in the hospital a total of 160 nurses.

Measurement of work environment variable by using dimensions from Sedarmayanti (2013) which include: lighting, noise, air temperature, air circulation, workspace size, privacy of the workspace, room layout, work security, work equipment, relations with colleagues, relations with superiors and subordinates. Job stress in this study is measured by using dimensions from Igor (1997) which include: intimidation and pressure from co-workers (company leaders and clients), differences between demands and available resources to carry out tasks and obligations, incompatibility with work, dangerous jobs, frustrating (boring or repetitive), excessive load. Especially for work stress variables, data processing is done by converting because all the statements in the work stress questionnaire are negative statements so for each data generated by processing by changing the code of the number in opposite. The performance in this study was measured using dimensions from Gomes (1997) which included: work quality, work knowledge, and work creativity.

This study used confirmatory factor analysis, by conducting a validity test by looking at the value of the Kaiser-MsyerOlkin measure of sampling (KMO) and measures of sampling adequacy (MSA). In this test the value obtained must be greater than 0.5 , which means that the analysis of factors is appropriate or suitable for use, and can be further processed (Malhotra, 2007). The work environment scale consists of 21 questionnaires and all valid questionnaires, the work stress scale consists of 13 questionnaires and 1 invalid questionnaire, the performance scale consists of 13 questionnaires and 1 invalid questionnaire. Reliability test with Cronbach Alpha value> 0.5 which means reliable, thus it can be said the work environment questionnaires, work stress and performance can be said to be trusted as a data collection tool in research.

\section{RESULT AND DISCUSSION}

\section{Result}

The instruments used in this study have been tested for validity and reliability. Validity test was done with KaiserMeyer-Olkin to measure the adequacy of sampling from the entire population, Measure Sampling Adequacy (MSA) was used to calculate the adequacy of the use of factor analysis and Barlett test of sphericity was used to test whether there were correlations between variables used. Factor test results of analysis and validity of work environment indicators, work stress and overall performance obtained KMO values above 0.5 in the operation of valid variables and can be used. Reliability test was carried out with Alpha Cronbach. The test results used Cronbach's Alpha Standard with a value of $>0.6$. The work environment variable has a Cronbach's Alpha value of 0.850 , the work stress variable has a Cronbach's Alpha value of 0.842 , and the performance variable has the value of Cronbach's Alpha 0.851 which all are declared reliable can be used as a research tool and data collection in this study.

Analysis of all tests almost showed good compatibility, including: Chi Square with value 1619.93, RMSEA ith value 0,073, ECVI with value 0,69, AIC with value 1393,93, CAIC with value 2591,96, and Fit Index with value 0,69. There are results and data information support the hypothesis : H1 (Better environment can increase working performance) with data T-Value 4,27 and data information support the hypothesis. H2 (Better environment can lower stress level.) with data T- Value 4,04 and data information support the hypothesis . H3 (Lower stress level can increase working performance.) with data T- Value 6,03 and data information support the hypothesis.

Mediation variable analysis can be done through two approaches, namely: difference in coefficient and multiplication. The first approach is done by conducting an examination through analysis with and without mediating variables, while the second method is done using the Sobel procedure (Hair, et. Al., 2013). Through the coefficient multiplication method, the results of the research hypothesis testing indicate the influence of work stress mediating variables between work environment variables on nurse performance, which work stress variables are used to connect between work environment and nurse performance. The results of testing the coefficient difference on the research model show that the work environment has a direct effect on nurses' performance with value of $t=4,27(>1,96)$, the work environment has a direct effect on work stress with a value of $t=4.04(>1.96)$ and on work stress affects the performance of nurses with a value of $t=6.03(>1.96)$. Thus it can be concluded that work stress can mediate the relationship of work environment to nurse performance. The work environment has a direct effect on work stress and nurse performance and has an indirect effect on nurse performance through mediating work stress.

\section{Discussion}

The results of testing the first hypothesis $\left(\mathrm{H}_{1}\right)$, found the results of the analysis support hypothesis $\mathrm{H}_{1}$, namely better environment can increase working performance. The dimension of the work environment used were air temperature, air circulation, room size, noise, lighting, room layout, work equipment, relationships with colleagues, relationships with superiors and subordinates, and job security. 


\section{International Advanced Research Journal in Science, Engineering and Technology}

Vol. 6, Issue 1, January 2019

This shows that the nurse's performance is determined by the work environment of the hospital itself. The better a work environment, the more positive the nurse's performance at the hospital will be, and vice versa if the work environment is bad, it will negatively affect the performance of the hospital nurse. The results of this study further support the results of previous studies namely Naharudin \& Sadegi (2013) also stated that the work environment is one of the factors that most influence performance compared to other factors. Jayaweera (2014) stated that companies must consider improving their work environment in order to improve employee performance. Omari \& Okasheh (2017) employee dissatisfaction with the work environment makes a decrease in performance consisting of uncomfortable work equipment, bad air and then lighting.

Workplaces always demand that every employee work productively. One way to keep employees working productively is by providing a comfortable and conducive work environment. A comfortable and conducive work environment cannot be separated from the factors of room coloring, office cleanliness, air transportation, lighting, security and noise in the work area thus it is worth noting, prepared and planned carefully because these things greatly affect the physical condition and psychology of employees, likewise the relationship between employees is also noteworthy. It also shows that it is very important for a hospital to always improve the work environment of each part of the nurse so that the service felt by patients is getting better because the nurse's performance is increasing besides a good work environment will also make nurses more comfortable in working and will in doing all work well so that home services will increase along with increasing nurse performance. The work environment is not only physical but also non physical which includes the atmosphere and relations between employees where in this case the hospital must be able to help establish good relations between employees both between superiors and subordinates.

Prevention of conflicts that occur in internal work should be avoided by routinely holding sharing as a forum for communication between nurses in solving problems encountered during work. It is very important for a hospital to always improve the comfort of the work environment so that the services felt by patients are getting better along with the increase in nurse performance. A good work environment makes nurses more comfortable in working and will do all the work well thus service increases along with the better performance of nurses. Prevention of conflicts that occur internally should be avoided by sharing as a forum for communication between problems encountered during work. It is very important for the hospital to always improve the performance of the nurse, along with the increase in nurse performance.

A good work environment makes nurses more comfortable in working and will do all the work well thus service increases along with the better performance of nurses. Fellow nurses can guide, advise, respect each other, and remind you if colleagues make mistakes thus a harmonious relationship is built. Nurses who have more knowledge in terms of science, can practice the knowledge that has been obtained to fellow nurses selflessly. Supervision activities carried out by the leader / person in charge of the room to the nurse is a form of assistance to develop nurses' expertise in achieving the goals of nursing care. In addition, the executive nurse will get a positive boost thus he would be glad to learn and improve its professional abilities. Willingness to learn and additional knowledge through ongoing nursing education and increasing nursing skills indirectly will improve nurse performance.

In the results of testing the second hypothesis $\left(\mathrm{H}_{2}\right)$, it was found that the results of the analysis support hypothesis $\mathrm{H}_{2}$ better environment can lower stress level. The dimensions of work stress used were coercion and pressure, workload, incompatibility with work, unrealistic targets, and hazardous work. This shows that work stress is determined by the work environment of the hospital.

Lower of work stress, the better work environment in the hospital and vice versa when the nurse has a high level of stress, the environment in the hospital is not good and has a negative influence on level of stress in work environment. The results of this study further support the results of other studies namely Thayer, et al, (2010) stated that employee dissatisfaction with the work environment has a negative influence and increases the level of work stress.

Khuong \& Yen (2016) in his research stating that the work environment is one of the factors that determine the level of work stress because the environment is the main thing that is directly felt by employees and has a direct effect as well Job stress becomes an intervening variable in the relationship of work environment and employee performance. The results of this study also further support that high stress levels due to the poor working environment felt by nurses, of course it is very appropriate that every nurse who does not experience stress in work has a better work environment and will focus on tasks carried out by nurses.

The stress experienced by someone is actually under self-control, because the problem is in the way someone perceives it. Every aspect of work can cause stress. The source of stress that causes a person is not optimal, or which causes a person to fall ill, not only comes from several types of stressors. Psychological symptoms that can be shown when someone experiences stress are anxiety, tension, confusion, irritability, frustration, anger, resentment (hatred), sensitivity, hyperreactivity, harboring feelings, withdrawal, depression, ineffective communication, feelings of isolation (estranged), job dissatisfaction, mental fatigue, decreased intellectual function, loss of concentration, and decreased self-confidence. Physiological symptoms that can be shown when a person experiences stress are increased heart rate, blood pressure, tendency to experience cardiovascular disease, increased secretion of stress hormones (eg adrenaline and nonadrenaline), gastrointestinal disorders (for example: gastric disease), increased frequency of physical injuries (work accident), physical fatigue and the possibility of chronic fatigue syndrome (chronic fatigue syndrome). 


\section{International Advanced Research Journal in Science, Engineering and Technology}

Vol. 6, Issue 1, January 2019

The physical environment in the hospital strongly supports nurse work activities. Physical environment such as adequate equipment, availability of facilities, and work atmosphere must always be maintained in use and improved so as to create a comfortable atmosphere and meet the standards of nurses' needs while working. The non-physical environment in the hospital strongly supports nurse work activities. Non-physical environment such as the relationship of nurses with units and between units, creating good communication between nurses and superiors, a solid system of cooperation when completing tasks and responsibilities of the hospital itself in meeting the needs of nurses, thus it is expected to minimize work stress. The results of this study further support that the work stress level of nurses due to bad environments can result in nurses not focusing on the tasks carried out.

In the results of testing the third hypothesis $\left(\mathrm{H}_{3}\right)$, it was found that the results of the analysis supported hypothesis $\mathrm{H}_{3}$, namely lower stress level can increase working performance. The performance dimensions used were work quality, work creativity, and work knowledge.

This shows that nurse performance is determined by work stress from the hospital. The lower the stress level of the nurse's work, the higher the performance of the nurse in the hospital and vice versa when the nurse has a high level of stress, the performance of the nurse will be in the hospital. The results of this study further support the results of other studies namely Jehangir, et al (2011) stated that work stress is one of the factors that influence the level of performance of female nurses in one hospital in Pakistan. Raman (2013) also stated that any increase in stress levels would reduce the level of employee performance.

Zafaar, et al (2015) stated that work stress has a negative correlation with performance where it is found that high levels of work stress will reduce the level of employee performance. Ahmed \& Job stress can be caused by many factors both intrinsic work, role conflict, relationships in work, career development and other work-related factors. The intrinsic factor of work can be a workload that is felt excessive for a nurse. The large number of jobs to be completed is not in accordance with normal time while on the other hand the quality of work becomes a demand that must be fulfilled. Stress factors can also occur due to bad relationships in work (relationships with superiors, coworkers and subordinates).

This happens if there are many negative values such as pressure, competition, job stress can be caused by many factors both intrinsic work, role conflict, relationships in work, career development and other work-related factors. The intrinsic factor of work can be a workload that is felt excessive for a nurse. The large number of jobs to be completed is not in accordance with normal time while on the other hand the quality of work becomes a demand that must be fulfilled. Stress factors can also occur due to bad relationships in work (relationships with superiors, coworkers and subordinates). This happens if there are many negative values such as pressure, competition.

The work stress experienced by nurses will certainly harm the hospital because of the decreased performance, high absenteeism and high turnover and ultimately causes the costs incurred to increase. The results of this study also further support that high levels of performance due to low stress levels on nurses, are very suitable that each nurse who does not experience stress in the work will produce a better level of performance because it focuses on work and will provide the best service to patients. The results of this study also further support that high levels of performance due to low stress levels in nurses, of course this is very appropriate that each nurse who does not experience stress in the work will produce a better level of performance because it will focus on the work provided and will provide the best service to patients.

The implications that can be given for this study are: temperature of the room according to the needs of the work space and the standard of storage of pharmaceutical drugs, procurement of measuring instrument of the humidity of the room, availability ventilation of the room, availability of air circulation to eliminate bad smell, room arrangement of furniture, relations between fellow colleagues, improving the level of work environment safety, the workload given to nurses, nurse's health level, stress can lead to health problems such as rapid fatigue, ease of panic, not calm, weight loss, decreased appetite, headaches and so on, it is necessary to hold regular health checks and consult on their health problems experienced, improve nurses skilss through a series of trainings to support and improve their ability and to encourage them improving their performance.

\section{CONCLUSION AND SUGGESTION}

\section{Conclusion}

The results that can be concluded from this study are that a good work environment improves the performance of nurses so that continuous improvements need to be made so that nurse performance can be achieved higher than specified. The work environment influences the level of stress of the nurse's work. Low levels of work stress are a direct influence of a good work environment so that it needs to be improved physically or non-physically in order to achieve a low level of work stress. Job stress affects nurse performance. Low levels of work stress will improve the performance of nurses, so it is necessary to emphasize the level of work stress so that nurse performance is achieved better. 


\section{International Advanced Research Journal in Science, Engineering and Technology}

Vol. 6, Issue 1, January 2019

\section{Research Limitations}

Limitations in this study can be taken into consideration for further research, while the limitations of the study include: the limitations of the number of samples and variables that affect the work environment on the performance of nurses mediated by work stress, this research is still very limited because it only examined the influence of the work environment on nurses' performance mediated by work stress, thus for the development of research it is suggested that future research can add other variables that influence nurse performance such as job satisfaction, work discipline, compensation, motivation, and others, this research is still limited in hospitals, thus for the development of research it is suggested that future research can be carried out in other hospitals, hotels, insurance companies, banks, leasing companies and others.

\section{Suggestion}

To develop research, it is recommended to include things that include improving the work environment physically and non-physically. A comfortable work environment will make the performance of nurses increase and patients feel satisfied. Improving the non-physical work environment in the form of relationships between fellow workers, work environment security, and information disclosure are equally important because they are related to the smooth communication in work. Conduct a series of training for nurses. In supporting and enhancing their abilities, training, seminars, exchange of nurses between hospitals are needed to compare expertise as a form of encouragement and motivation for nurses in completing work and handling work stress for nurses. Establish a crisis center to help nurses deal with the potential for stress in their work.

\section{REFERENCES}

[1]. Ahmed, A. \& Ramzan, M. (2013). Effects of Job Stress on Employees Job Performance A Study on Banking Sector of Pakistan. IOSR Journal of Business and Management (IOSR-JBM). Volume 11, Issue6, PP 61-68.

[2]. Anderson, E, S., Coffey, S. B., and T. R. Byerly. (2002). "Formal organizational initiatives and informal workplace practices: Links to workfamily conflict and job-related outcomes," Journal of Management, vol. 28, p. 787.

[3]. Borman, W, C., \& Motowidlo, S, J. (1993). "Expanding the criterion domain to include elements of contextual performance," in Personnel Selection in Organizations, N. Schmitt and W. C. Borman, Eds. San Francisco: Jossey-Bass, pp. 71-98.

[4]. Campbell, J, P., McHenry, J, J., \&Wise, L, L. (1990). "Modeling job performance in a population of jobs," Personnel Psychology, vol. 43, pp. 313-33.

[5]. Campbell, J, P., McCloy, R, A., Oppler, S, H., \& Sager, C, E. (1993). “A theory of performance,” in Personnel Selection in Organizations, N. Schmitt and W. C. Borman, Eds. San Francisco: Jossey-Bass, pp. 35-70.

[6]. Hair, J. F., Black, W. C., \& Babin, B. J. (2013). Multivariate Data Analysis (7 ed.). New York: Pearson.

[7]. Hunter, J, E. \& R. F. Hunter, "Validity and utility of alternative predictors of job performance," Psychological Bulletin, vol. 96, pp. 72-98, (1984).

[8]. Gomes, F. C. (1997). Manajemen Sumber Daya Manusia. Yogyakarta: Andi Offset.

[9]. Igor, S. (1997). Pekerjaan Anda Bagaimana Mendapatkannya Bagaimana Mempertahankannya. Alih Bahasa: Monica. Solo. Dabara.

[10]. Jayaweera, T. (2015). Impact of Work Environmental Factors on Job Performance, Mediating Role of Work Motivation: A Study of Hotel Sector in England. International Journal of Business and Management; Vol. 10, No. 3

[11]. Jehangir, M., Kareem, N., Khan, A., Jan, M. T., \& Soherwadi, S. (2011). Effects Of Job Stress On Job Performance \& Job Satisfaction. Interdisciplinary JournaL Of ContemporarY Research In Business. Vol 3, No 7.

[12]. Khuong, M.N., \& Yen, V.H. 2016. Investigate the Effects of Job Stress on Employee Job Performance - A Case Study at Dong Xuyen Industrial Zone, Vietnam. International Journal of Trade, Economics and Finance. Vol. 7, No. 2.

[13]. Malhotra, N. K., \& Dash, S. (2011). Marketing Research An Applied Orientation (11 ed.). England: Pearson.

[14]. Noah, Y. \& Steve, M. (2012). Work Environment and Job Attitude Among Employees in A Nigerian Work Organization. Journal of ustainable Society 1(2), 36-43.

[15]. Naharudin, M, N., \& Sadegi, M. (2013). Factors of Workplace Environment that Affect Employees Performance: A Case Study of Miyazu Malaysia. International Journal of Independent Research and Studies - IJIRS. Vol. 2, No.2. 66-78

[16]. Omari, K, A., \& Okasheh, H. (2017). The Influence of Work Environment on Job Performance: A Case Study of ngineering Company in Jordan. International Journal of Applied Engineering Research ISSN 0973-4562 Volume 12, Number 24. pp. 15544-15550.

[17]. Render, B. \& Heizer, J. (2001). Prinsip-prinsip Manajemen Operasi : Operations Management. Jakarta Salemba Empat.

[18]. Rivai, V. 2008. Manajemen Sumber Daya Manusia untuk Perusahaan .PT.Raja Grafindo Persada: Jakarta.

[19]. Robbin S.P. \& Judge, T.A. (2012). Organizational Behavior. Boston: Pearson

[20]. Schultz, D., \& Schultz, S E. (2006). Psychology \& Work Today Ninth Edition. New Jersey: Pearson Education. Inc.

[21]. Sedarmayanti. (2013). Manajemen Sumber Daya Manusia: Reformasi Birokrasi Dan Manajemen Pegawai Negeri Sipil. Bandung: PT Refika Aditama.

[22]. Thayer, J, F., Verkuil, B., Brosschott, J.F., Kampshoroer, K., West, A., Sterling, C., Christe, I,C., Abernethy, D,R,. Sollers, J,J., Cizza, G., Marques, A,H.,\& Stenberg, E, M. 2010. Effects of the physical work environment on physiological measures of stress. European Journal of Cardiovascular Prevention and Rehabilitation. Vol 17 No 4.

[23]. Tuckman, B, W. (1978). Conducting Educational Research, $2^{\text {nd }}$ Edition New York: Harcourt brace Jovanich.

[24]. Viswesvaran, C. and Ones, D, S. (2000). "Perspectives on models of job performance," International Journal of Selection and Assessment, vol. 8 , no. 4 , pp. $216-226$.

[25]. Vischer, J. C. (2008). Towards an environmental psychology of workspace : How people are affected by environments for work. Architectural Science Review. 51(2), 97-108.

[26]. Zafaar, Q., Ali, A., Hameed, T., Ilyas, T., \& Younas, H, I. 2015. The Influence of Job Stress on Employees Performance in Pakistan. American Journal of Social Science Research. Vol. 1, No. 4, pp. 221-225. 